\title{
Prevalence of Candida tropicalis and Candida krusei in onychomycosis in João Pessoa, Paraiba, Brazil from 1999 to 2010
}

\author{
JULIANA M.M. ARRUA ${ }^{1,3}$, LUIS A.S. RODRIGUES ${ }^{3}$, \\ FILLIPE O. PEREIRA ${ }^{2}$ and EDELTRUDES O. LIMA ${ }^{3}$ \\ ${ }^{1}$ Universidad Nacional de Asunción, Campus Universitário, \\ Mariscal Estigarribia, Km 11,5, C.P. 2169, XI, San Lorenzo, Paraguay \\ ${ }^{2}$ Universidade Federal de Campina Grande, Centro de Educação e Saúde, \\ Unidade Acadêmica de Saúde, Olho D’Água da Bica, s/n, 58175-000 Cuité, PB, Brasil \\ ${ }^{3}$ Universidade Federal da Paraíba, Departamento de Ciências Farmacêuticas, Laboratório de Micologia, \\ Campus Universitário, Castelo Branco, 58051-900 João Pessoa, PB, Brasil
}

Manuscript received on November 2, 2013; accepted for publication on January 21, 2015

\begin{abstract}
Over time, as the etiology of onychomycosis has developed, yeasts from the genus Candida have emerged as important etiological agents. This study aimed to determine the frequency of yeast caused onychomycosis in Joao Pessoa, Paraíba, Brazil from 1999 to 2010. A retrospective study from January 1999 to December 2010 evaluated the results of onychomycosis positive direct mycological exams (DME) - for yeast and realized in the Hemato ${ }^{\circledR}$ Clinical Laboratory. Women were the most affected by onychomycosis which occur preferentially in adults, and the toenails are the favorite yeast targets. The prevalent yeasts were Candida tropicalis and C. krusei.
\end{abstract}

Key words: Candida non-albicans, epidemiology, candidiasis, nails.

\section{INTRODUCTION}

Onychomycosis are common fungal infections affecting nails, which account for 15 to $40 \%$ of nail diseases (Dahdah and Scher 2006, Zanardi et al. 2008). Their prevalence is growing, and can be explained by factors such as increased incidence of immunodeficiency, population age, improved medical surveillance, nail care, and genetic susceptibility, along with smoking, environmental (geography, climate), and behavioral factors. For example, the prevalence of onychomycosis in swimmers is at least three times more than for non-

Correspondence to: Juliana Moura Mendes Arrua

E-mail:jmmarrua@gmail.com swimmers (Faergemann and Baran 2003, Tosti et al. 2005, Dahdah and Scher 2006, Zanardi et al. 2008). Among the etiologic agents of onychomycosis yeasts, dermatophytes and non-dermatophyte filamentous fungi stand out, with dermatophytes being considered the main causal agents, followed by yeasts (Faergemann and Baran 2003, Ballesté et al. 2003, Tosti et al. 2005). Onychomycosis caused by yeast have become increasingly common in medical practice, and have come to represent $75 \%$ of all cases in Líbya (Ellabib et al. 2002), 59.1\% in Rome (Mercantini et al. 1996), 49.1\% in Rio de Janeiro (Araujo et al. 2003), and 46.3\% in MaringáPR, Brazil (Souza et al. 2007). Due to the variety 
of etiologic agents, it has become difficult for the clinician to decide which therapeutic approach should be established. In addition, onychomycosis are often treated exclusively as a cosmetic problem of relatively minor importance, without regard for the real impacts of the disease (Araujo et al. 2003, Lima et al. 2008). Onychomycosis are very uncomfortable for most patients and often cause great disability and pain, adversely affecting the patient's sense of well-being and self-esteem, including financially in professions such as food handlers, receptionists, secretaries and employees of sport clubs (Araujo et al. 2003, Dahdah and Scher 2006). According to Joish and Armstrong (2002), onychomycosis are the most difficult of superficial fungal infections to treat, and even when medication is appropriate to the etiologic agent identified, cure is not always obtained, having frequent relapses. Khosravi et al (2008) described that isolates from the nails (Candida albicans and C. non-albicans) were susceptible to amphotericin $\mathrm{B}$, itraconazole, fluconazole, and ketoconazole, and emphasized the importance of routine identification and susceptibility testing of onychomycosis isolates (both Candida, and specially non-albicans Candida species) to help in the selection of antifungal agents, and successful treatments. Given the high incidence of onychomycosis in the country and the scarcity of epidemiological studies in the city of João Pessoa; the present study aimed to determine the frequency of yeasts as etiological agents of onychomycosis, identified in the Hemato ${ }^{\circledR}$ Clinical Laboratory located in João Pessoa, Paraiba, Brazil. For this purpose, local laboratory test records were analyzed. Afterwards, we analyzed tests performed for all patients with suspected onychomycosis between January 1999 and December 2010; 693 patients had positive results using the Direct Mycological Exam (DME). In this exam, nail fragments were examined searching for fungal elements such as hyphae or blastoconidia by direct microscopic examination using 20\% KOH/DMSO. Then, exam cultures were confirmed in 542 of these samples. From the 693 patients, $87.5 \%$ were female, $59.2 \%$ were people of color, and the most affected age group was from 41 to 60 years; representing $41 \%$ of patients studied; $24 \%$ were 61 to 80 years, and $24 \%$ were 21 to 40 years, demonstrating the prevalence of this disease in adults and elderly (Figure 1). The lesion location was not specified in 31 records. In other records, plotted in Figure 2, toenails were the most affected, representing 44\%, followed by the fingernails with $38 \%$. In Table I, which provides the culture results, it is observed that

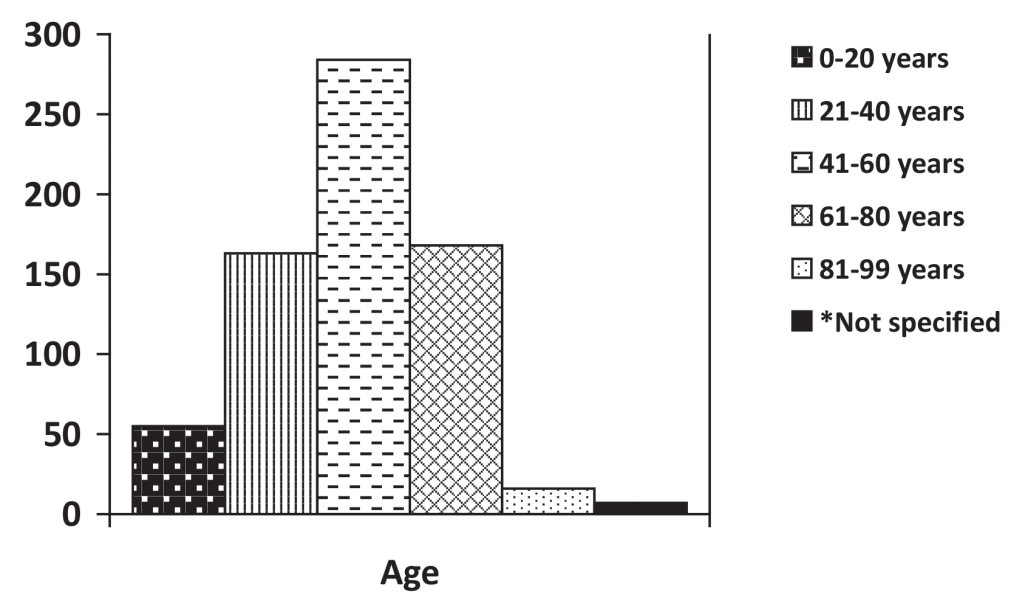

Figure 1 - Distribution of cases of onychomycosis by age in João Pessoa-PB in the period 1999 to 2010 . 
TABLE I

Distribution of yeast species found in the examination cultures.

\begin{tabular}{ccc}
\hline YEAST & NUMBER OF CASES & PREVALENCE \\
\hline Candida sp. & 13 & $2 \%$ \\
Candida tropicalis & 158 & $24 \%$ \\
Candida krusei & 151 & $23 \%$ \\
Candida albicans & 75 & $11 \%$ \\
Candida guilliermondii & 126 & $19 \%$ \\
Candida stellatoidea & 07 & $1 \%$ \\
Candida parapsilosis & 08 & $1 \%$ \\
Candida glabrata & 04 & $0,6 \%$ \\
Rhodotorula rula & 01 & 0,1 \\
\# Negative cultures & 122 & $18 \%$ \\
\hline
\end{tabular}

of 665 culture tests: $24 \%$ cases were positive for $C$. tropicalis, $23 \%$ for C. krusei, 11\% for C. albicans and $2 \%$ did not have the species specified, only Candida spp. A full 18\% were negative, which can be attributed to the non-uniform distribution of fungi in nails, and also to the lack of proper orientation to the patient on how to proceed before the test completion. These results support those reported in the literature on the presence of Candida species as causative agents of onychomycosis, with C. albicans species described as prevalent in most works (Araujo et al. 2003, Souza et al. 2007, Brilhante et al. 2005), including a study performed in João Pessoa-PB in 2002 (Pontes et al. 2002). However, this study, 1999-2010 from data analyzed demonstrated that $C$. tropicalis and C. krusei were the main yeasts causing Onychomycosis in João Pessoa during the last 11 years, emphasizing the importance of non-albicans Candida yeasts as causes of onychomycosis. In this retrospective study, there were also confirmations of onychomycosis using cultures in $81.6 \%$ of cases, a total close to what was found by Pontes et al (2002) in a study conducted in João Pessoa-PB positive in $75 \%$ of cases, confirming direct mycological exam (DME) positives for yeasts. With respect to most of patients being adults $(65 \%)$ and females $(87.5 \%)$, it corroborates the studies performed by Martins et al (2007) and Brilhante et al (2005). Probably women are more likely to be exposed to cleaning product aggressions, as well as to contact with water, and to shoes that promote trauma to nails, favoring fungi penetration, which also explains the prevalence of onychomycosis in toenails (Ellabib et al. 2002, Brilhante et al. 2005, Martins et al. 2007). Given the results presented, it can be concluded that onychomycosis affects both the toenail and women more frequently, and the predominant species of the Candida genus are C. krusei and C. tropicalis. It has been shown the growth and importance of such infections caused by non-albicans Candida species, and thus, this retrospective study provides data revealing changes in onychomycosis's epidemiological patterns and etiology possibly useful both for diagnosis and treatment.

\section{ACKNOWLEDGMENTS}

We want to thank Dr. Alexandre Magno Pimentel de Oliveira for access to the data, making possible the realization of this work.

\section{RESUMO}

Ao longo do tempo, se modificou a etiologia das onicomicoses, leveduras do gênero Candida têm emergido como agentes etiológicos importantes. O objetivo desse trabalho foi determinar a frequência de onicomicoses causadas por leveduras em João Pessoa, Paraíba, Brasil de 1999 a 2010. Um estudo retrospectivo de janeiro de 1999 a dezembro de 2010 avaliou os resultados de exames 
micológicos diretos (EMD) positivos para leveduras provenientes de onicomicoses, realizados no Laboratório Clínico Hemato $^{\circledR}$. As mulheres foram as mais afetadas por onicomicoses, as unhas dos pés são os alvos preferidos e ocorrem preferencialmente em adultos. As leveduras prevalentes foram Candida tropicalis e C. krusei.

Palavras chave: Candida não-albicans, epidemiologia, candidíases, unhas.

\section{REFERENCES}

Araujo AJG, Bastos OMP, SOUZA MAJ AND OliveIRA JC. 2003. Occurrence of onychomycosis among patients attended in dermatology offices in the city of Rio de Janeiro, Brazil. An Bras Dermatol 78: 299-308.

BALLESTÉ R, MOUSQUÉS NAND GEZUELE E. 2003. Onicomicosis. Revisión del tema. Rev Méd Urug 19: 93-106.

BRILHANTE RSN, CORDEIRO RA, MEDRANO DJA, ROCHA MFG, MONTEIRO AJ AND CAVALCANTE CSP. 2005. Onychomycosis in Ceará (Northeast Brazil): epidemiological and laboratory aspects. Mem Inst Oswaldo Cruz 100(2): 131-135.

DAHDAH MJ AND SCHER RK. 2006. Onychomycosis - An Overview. US Dermatology review (Reference Section): 1-3.

Ellabib MS, Agaj M, Khalifa Z and Kavanagh K. 2002. Yeasts of genus Candida are the dominant cause of onychomy cosis in Libyan women but not men: results of a 2-year surveillance study. Br J Dermatol 146: 1038-1041.

FAERGEMANN J AND BARAN R. 2003. Epidemiology, clinical presentation and diagnosis of onychomycosis. Br J Dermatol 149(65): 1-4.
JOISH VN AND ARMSTRONG EP. 2002. Newer drugs and overall costs of treating onychomycosis. Rev Iberoam Micol 19(3): 130-132.

KHOSRAVI AR ET AL. 2008. Candida species isolated from nails and their in vitro susceptibility to antifungal drugs in the department of Dermatology (University of Tehran, Iran). J Mycol Med. doi:10.1016/j.mycmed.2008.09.003

LIMA KM, RËGO RSM, MONTENEGRO F AND SILVEIRA NSS 2008. Fungal species causing onychomycosis in Recife, Pernambuco. RBAC 40(2): 107-110.

Martins EA, GUERRER LV, CUNHA KC, SOARES MMCN AND ALMEIDA MTG. 2007. Onychomycosis: clinical, epidemiological and mycological study in the municipality of São José do Rio Preto. Rev Soc Bras Med Trop 40(5): 596-598.

Mercantini R, MARSElla R AND Moretto D. 1996. Onychomycosis in Rome, Italy. Mycopathologia 136: 25-32.

PONTES ZB, Lima EO, OLIVEIRA NM, Dos SANTOS JP, RAMOS AL AND CARVAlHo MF. 2002. Onychomycosis in João Pessoa City, Brazil. Rev Argent Microbiol 34(2): 95-99.

Souza EAF, Almeida LMM, GuILHERmetti E, Mota VA, Rossi RM AND SVIDZINSKI TIE. 2007. Freqüência de onicomicoses por leveduras em Maringá, Paraná, Brasil. An Bras Dermatol 82(2): 151-156.

Tosti A, HAY R AND ARENAS-GuZMAn R. 2005. Patients at risk of onychomycosis-risk factor identification and active prevention. J Eur Acad Dermatol Venereol 19(1): 13-16.

Zanardi D, Nunes DH, PACheCo AS, TubONE MQ AND SOUZA FILHO JJ. 2008. Evaluation of the diagnostic methods of onychomycosis. An Bras Dermatol 83(2): 119-124. 